\title{
Carbon monoxide in intensive care medicine-time to start the therapeutic application?!
}

\author{
Ulrich Goebel ${ }^{1 *}$ (D) and Jakob Wollborn ${ }^{2}$
}

\author{
* Correspondence: ulrich.goebel@ \\ sfh-muenster.de \\ ${ }^{1}$ Department of Anaesthesiology \\ and Critical Care, St \\ Franziskus-Hospital, \\ Hohenzollernring 70, 48145 \\ Münster, Germany \\ Full list of author information is \\ available at the end of the article
}

\begin{abstract}
Carbon monoxide (CO) is not only known as a toxic gas due to its characteristics as an odorless molecule and its rapid binding to haem-containing molecules, thus inhibiting the respiratory chain in cells resulting in hypoxia. For decades, scientists established evidence about its endogenously production in the breakdown of haem via haem-oxygenase ( $\mathrm{HO}-1)$ and its physiological effects. Among these, the modulation of various systems inside the body are well described (e.g., antiinflammatory, anti-oxidative, anti-apoptotic, and anti-proliferative). Carbon monoxide is able to modulate several extra- and intra-cellular signaling molecules leading to differentiated response according to the specific stimulus. With our growing understanding in the way $\mathrm{CO}$ exerts its effects, especially in the mitochondria and its intracellular pathways, it is tempting to speculate about a clinical application of this substance. Since HO-1 is not easy to induce, research focused on the application of the gaseous molecule $\mathrm{CO}$ by itself or the implementation of carbon monoxide releasing molecules (CO-RM) to deliver the molecule at a time- and dose dependently safe way to any target organ. After years of research in cellular systems and animal models, summing up data about safety issues as well as possible target to treat in various diseases, the first feasibility trials in humans were established. Upto-date, safety issues have been cleared for low-dose carbon monoxide inhalation (up to $500 \mathrm{ppm}$ ), while there is no clinical data regarding the injection or intake of any kind of CO-RM so far. Current models of human research include sepsis, acute lung injury, and acute respiratory distress syndrome as well as acute kidney injury. Carbon monoxide is a most promising candidate in terms of a therapeutic agent to improve outbalanced organ conditions. In this paper, we summarized the current understanding of carbon monoxide's biology and its possible organ targets to treating the critically ill patients in tomorrow's ICU.
\end{abstract}

Keywords: Carbon monoxide, Haeme-oxygenase-1, Acute respiratory distress syndrome, Idiopathic pulmonary fibrosis, Acute kidney injury, Extracorporeal circulation, Transplantation

\section{Background}

Being an odorless and difficult to sense gas, carbon monoxide (CO) was usually referred to as the "silent killer" with a myriad of published and unpublished fatal accidents, mostly due to incomplete combustion of organic material or explosions [1]. The high affinity of $\mathrm{CO}$ to hemoglobin was used as one possible explanation for the toxic

(c) The Author(s). 2020 Open Access This article is distributed under the terms of the Creative Commons Attribution 4.0 International License (http://creativecommons.org/licenses/by/4.0/), which permits unrestricted use, distribution, and reproduction in any medium, provided you give appropriate credit to the original author(s) and the source, provide a link to the Creative Commons license, and indicate if changes were made. 
effects [2, 3]. Although different symptoms of $\mathrm{CO}$ intoxications were seen (ranging from headache and fatigue to nausea and vomiting, confusion, and convulsion and finally death), it took more than 50 years to prove Paracelsus' maxim to be true: "only the dose makes the poison."

Carbon monoxide was recognized and first described in 1925 to be more than just a toxic, odorless and thus very dangerous gaseous molecule [4-7]. Since its discovery as an endogenously generated product in the degradation process of haem, a multitude of in-vitro and in-vivo experiments have been performed to analyse its effects in a variety of systems and diseases and shed light on the impact as well as the molecular mechanism of this interesting gas [8-16]. The finding, that the catalytic degradation and conversion of hemoglobin into its parts (i.e., biliverdin, iron and carbon monoxide) is an enzyme-triggered process directed research into a new direction. Tenhunen and Schmidt first identified the enzyme responsible to produce CO endogenously: hemoxygenase (HO) [17]. Haem-oxygenase-1 and -2 (HO-1 and -2) have been demonstrated to be the (stress-) inducible and constitutive isoforms of the rate-limiting enzyme, responsible to produce CO [18]. While the knowledge of significance only emerged slowly over the years, it was in 1999 that the case of a child with proven HO-1 deficiency was reported, suffering from a variety of organ dysfunction [19]. Since CO is thought to be the crucial product of the $\mathrm{HO}$ breakdown, a generation of scientist was in search for non-toxic but yet potent HO-1 inducible drugs. Among various agents in question, anesthetics (e.g., isoflurane and sevoflurane) were found to be capable of a significant HO-1 induction providing not only an upregulation of HO-1, but also organ protection, while being clinically safe [20-22].

The pure substance of carbon monoxide itself may alter various diseases in all kinds of experimental physiological systems, settings, and target-organs (i.e., antiinflammatory, anti-apoptotic, anti-oxidative, anti-proliferative, and vasodilative etc.); see Fig. 1 [14, 23-26]. These include potential disease, which may be of interest in the ICU (pulmonary arterial hypertension [PAH], acute respiratory distress syndrome [ARDS], acute kidney injury $[\mathrm{AKI}]$, sepsis, transplant settings, and the use of extracorporeal circulation units [ECMO, ECLS]) [27]. However, the straight clinical use of CO via inhalational administration-which would be the logical consequence of the above said-is currently difficult to implement. Due to the relatively low solubility of molecular CO in water (about $1 \mathrm{mM}$ ), its distribution and allocation to target tissues seems limited. In order to reach sufficient concentration at target side, enormous concentrations of inhaled $\mathrm{CO}$ would be needed. Apart from this, $\mathrm{CO}$ reacts relatively fast with other serum proteins, which in turn limits its potential (inter-)action at the target organ side (as long as it is not the pulmonary system).

The direct high toxicity due to the inhalation of even putative "low doses" of carbon monoxide triggered new methods to apply defined doses at a pre-set organ or tissue within a defined time-window [28]. In recent years (and beside the other well established gaso-transmitters like nitric oxide, hydrogen sulfide or argon), carbon monoxide has attracted rising attention, since scientists were able to design and produce specific small molecules, so called carbon monoxide releasing molecules (CO-RMs), meeting the specific requirements such as solubility, low toxicity, and triggered release of $\mathrm{CO}$ [15, 29-33]. CO-RMs show comparable effects (e.g., anti-inflammatory impact) as the carbon monoxide gas [34]. The well-known preference of $\mathrm{CO}$ toward metal compounds 


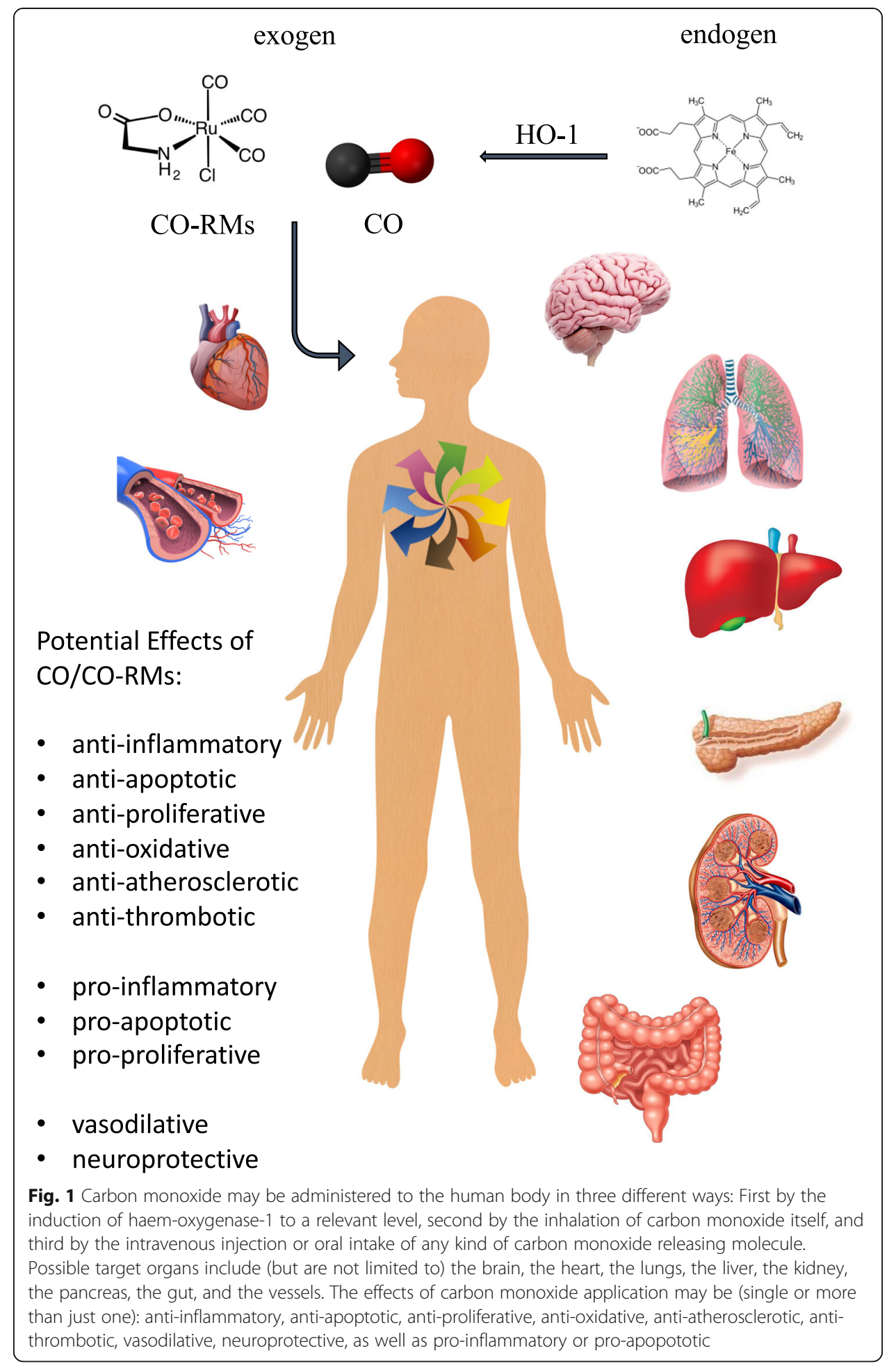

(e.g., the iron molecule in hemoglobin) and the knowledge about transition metals in organic chemistry predicted the way of the development of CO-RMs. Although the first $\mathrm{CO}-\mathrm{RMs}$ were able to deliver $\mathrm{CO}$ at controlled amounts and toward specific tissue, the problem of the toxicity of the transition metal backbone (e.g., ruthenium in CORM-2 or molybdenum in ALF186 and ALF062) are still a problem. In contrast, CORM-A1 
presented with a boron containing molecule and a longer half-life of approx. $21 \mathrm{mi}-$ nutes [35].

Recently, a new class of enzyme-triggered CO-RMs (ET-CORM) has been introduced. Enzyme-triggered CO-RMs have been designed in order to improve target-tissue concentration of $\mathrm{CO}$ since ET prodrugs are activated time-dependently by serum esterases achieving site-specific CO-release [30]. Moreover, the modification of the outer ligand sphere by peptides may support the controlled release of $\mathrm{CO}$ at the target side [36, 37]. While these substances have not been analyzed in-vivo up-to-date, there is some evidence about their potential in HUVECs, displaying the activation of Nrf-2 and HO-1 by counteracting TNF- $\alpha$ induced inflammation and inhibiting VCAM-1 $[38,39]$.

Although all kinds of CO-RMs may deliver $\mathrm{CO}$ in a multitude of different ways and kinetics due to different stimuli $[28,40,41]$, the beneficial effects of $\mathrm{CO}$ on organ function still need to be evaluated in the context of the whole organism. Very special attention is necessary in terms of safety issues regarding the metabolic fate of either the donor molecule, the specific transition metal backbone, and CO itself [42, 43].

This review will discuss the potential human target organs, mechanisms, and strategies to implement carbon monoxide independent of the source of administration (the gaseous molecule $\mathrm{CO}$ or any kind of CO-RM) according to the published literature of $\mathrm{CO}$-administration in humans to the benefit of disease prevention and therapeutic application at the level of a human intensive care medicine setting.

\section{Carbon monoxide biology and mechanism of action}

Both carbon monoxide and it's artificial releasing molecules exert a wide range of biological effects including a variety of different intracellular pathways. Important to know that the transition metals in CO-RMs may affect the above outlined beneficial effects of $\mathrm{CO}$. The main effects of $\mathrm{CO}$ may be summarized as follows: anti-inflammatory [8], anti-thrombotic [44], anti-oxidative [45], anti-proliferative [46], anti-apoptotic [11], anti-atherosclerotic [47], neuroprotective [11, 48], and vasodilative [49]. Of note, $\mathrm{CO}$ may dose-dependently exert certain "pro"-effects: pro-inflammatory, pro-apoptotic, and pro-proliferative, depending on the individual setting [50-52].

The molecular mechanism is well understood-a summary is given in Fig. 2. Of note, not all known target proteins or structures have been implemented in this figure to facilitate the understanding of the main processes. Carbon monoxide preferably targets haem-containing proteins, such as hemoglobin, the mitochondria oxidases, the soluble guanylyl cyclase, or the enzymes necessary for reactive oxygen species generation $[15,53]$. The anti-inflammatory effects have been well described by Otterbein et al. He was able to demonstrate that $\mathrm{CO}$ differentially affects the cytokine system, decreasing the expression of pro- and increasing the expression of anti-inflammatory interleukins [14]. These findings are consistent throughout the literature in different models, including LPS-stimulated macrophages microglia cells $[54,55]$. Carbon monoxide confers these anti-inflammatory effects through the activation of the mitogen activated protein kinases (p38, ERK, and JNK) in response to different types of stressors [16]. In detail, $\mathrm{CO}$ regulates its anti-inflammatory and its anti-apoptotic effects via an activation of the 


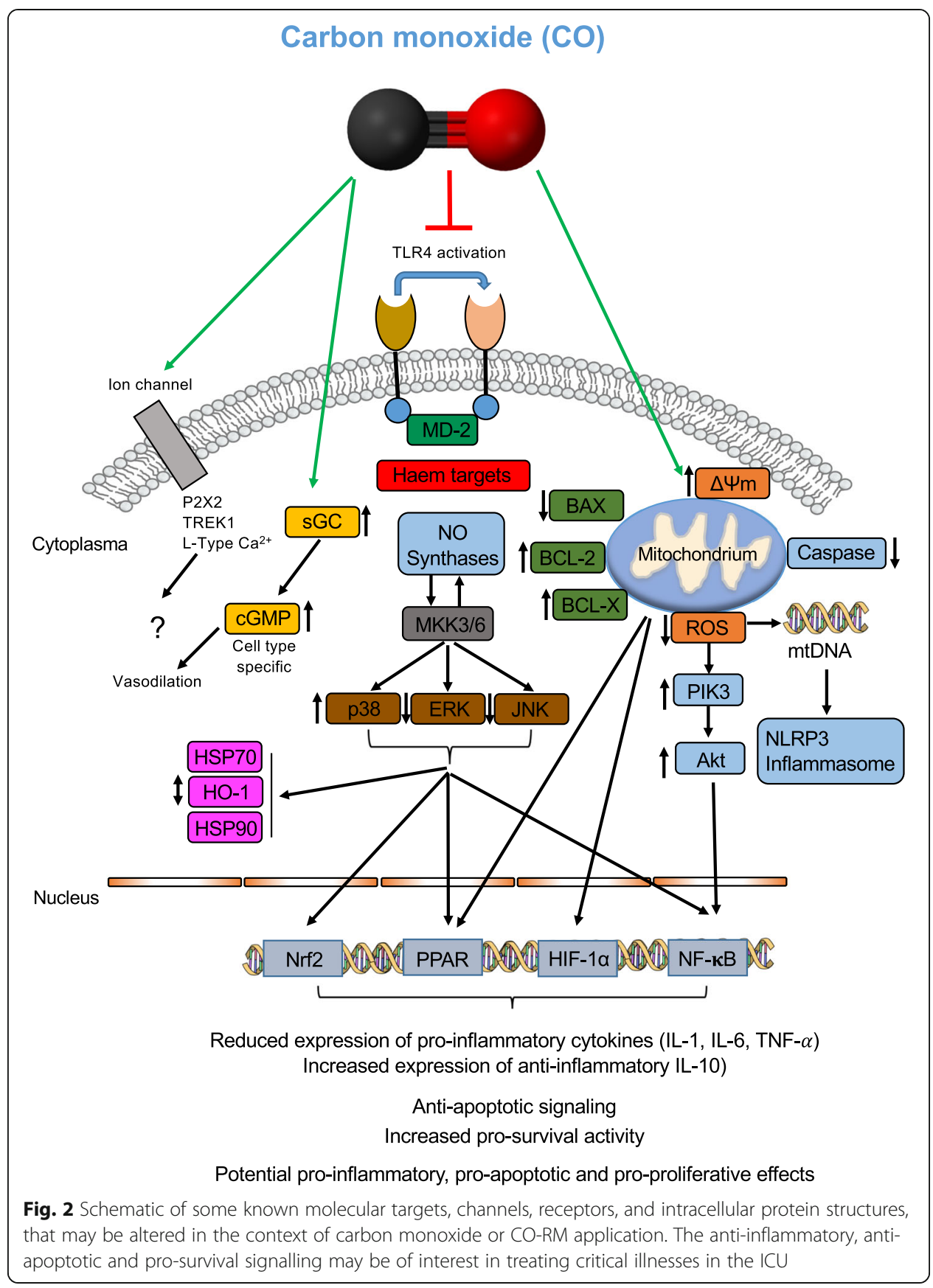

MKK3/p38 $\beta$ MAPK pathway $[12,14]$. The soluble guanylyl cyclase (sGC) may be affected by $\mathrm{CO}$ and contributes to the alteration of nitric oxide synthases (NOS), which in term modifies the expression of the MAPK $[56,57]$. The regulation of JNK or ERK in the context of carbon monoxide application has been described to varying extents in different cell types and conditions [10, 26]. Part of the antiinflammatory modulation may be the inhibition of TLR-4 trafficking while interacting with caveolin-1 at the outer plasma membrane $[58,59]$. The exact intracellular mechanisms of carbon monoxide will not be discussed in detail; the specific literature will give answers [16]. 


\section{Potential targets of $\mathrm{CO}$ in intensive care medicine}

Almost every organ system and tissue has been subjected to $\mathrm{CO}$ treatment in the last decades [40]. All species have been part of a research that well evaluated the effects of any disease ranging from malaria to stroke and from heart disease to compartment syndromes and breaking down the exact molecular mechanism of its terms of action [60-63]. Several of these studies point toward important conditions that are most commonly treated on intensive care units. While there were many promising studies in human beings, most of them failed to prove effectiveness, did not reach the statistical significance, or have been withdrawn for a variety of reasons [64-74] (see Table 1). Apart from that, all studies were able to provide data, that the administration of low-doses of carbon monoxide seems safe. Carbon monoxide concentration, duration of application, and hemoglobin levels during or after inhalation did not exceed FDA approved limits.

\section{Carbon monoxide in pulmonary diseases}

Pulmonary arterial hypertension (PAH) is a rare disorder which is mainly characterized by a slow but ongoing chronic inflammation and thus obliteration of small pulmonary arteries. This leads finally to an increase in pulmonary arterial pressure and resistance and consequently to the failure of the right ventricle. The understanding of the underlying mechanism evolved well over recent years-nevertheless, therapies including receptor antagonists against endothelin or PDE- 5 inhibitors only show moderate effectiveness, especially in terms of protecting the right ventricle [75]. Since no cure exists to treat PAH causal, prognosis remains very poor unless lung transplantation is an option. Concerning the anti-inflammatory effects of carbon monoxide, an option may be the inhalation of $\mathrm{CO}$ regarding its direct impact in the pulmonary system.

In 2012, a clinical trial was initiated (NCT01523548: carbon monoxide therapy for severe pulmonary arterial hypertension) which unfortunately was withdrawn sometime later. Drug administration of $\mathrm{CO}$ was considered to be in an increasing manner, starting with $150 \mathrm{ppm} \times 3 \mathrm{~h}$ once weekly (week 1 ), $150 \mathrm{ppm} \times 3 \mathrm{~h}$ twice weekly (week 2 ), and ending with $150 \mathrm{ppm} \times 3 \mathrm{~h}$ three times a week (week 3-16). The primary outcome was clearly defined as the evidence of a $20 \%$ decrease in pulmonary vascular resistance post-therapy when compared to pre-therapy value. While not being executed, this study plan represents one of the promising options to treat a rare but severe disease, especially in patients where left heart failure is not the reason for PAH. The antiinflammatory effects of $\mathrm{CO}$ would most likely directly interact with the endothelial cells to counteract ongoing obliteration.

\section{Acute respiratory distress syndrome}

The acute respiratory distress syndrome (ARDS) is a common complication of a variety of diseases requiring intensive care treatment. It may be characterized by a severe acute lung injury (ALI) and hypoxemic respiratory failure. The overall mortality rate ranges up to 40\% [76]. Among other risk factors, sepsis is considered a major contributor for ARDS development during ICU stay [77]. Since other treatment options failed to provide sufficient data to reduce morbidity and mortality, there is a strong need to develop new strategies in treating both ALI and ARDS. 
Table 1 History of carbon monoxide inhalational clinical trials including healthy volunteers and patients. The lower part represents the studies, which have been withdrawn for various reasons. (This list is not exhaustive)

\begin{tabular}{|c|c|c|c|c|c|c|}
\hline Ref. & Year & First author & $\begin{array}{l}\text { Number of } \\
\text { participants }\end{array}$ & Carbon monoxide dose & $\mathrm{CO}-\mathrm{Hb}$ & Outcome/marker \\
\hline 52 & 1973 & R.D. Steward & Not reported & 100 ppm for $8 \mathrm{~h}$ & $11-13 \%$ & Feasibility study \\
\hline 53 & 1975 & J.E. Peterson & 22 volunteers & $\begin{array}{l}50,100, \text { and } 200 \mathrm{ppm} \\
\text { for } 5.25 \mathrm{~h}\end{array}$ & $1-20 \%$ & $\begin{array}{l}\text { Feasibility study, check of } \\
\text { Coburn-Forster-Kane } \\
\text { equation }\end{array}$ \\
\hline 55 & 1997 & M. Hausberg & 10 volunteers & $\begin{array}{l}30 \text { min of } 1000 \text { ppm } \\
\text { followed by } 30 \text { min } \\
\text { of } 100 \text { ppm }\end{array}$ & $\begin{array}{l}8.3 \pm \\
0.5 \%\end{array}$ & $\begin{array}{l}\text { Acute sympathetic and } \\
\text { hemodynamic effects, } \\
\text { no differences between } \\
\text { groups }\end{array}$ \\
\hline 54 & 2001 & Ren & 11 subjects & $\begin{array}{l}4000 \mathrm{ppm} \text { until } \\
\mathrm{CO}-\mathrm{Hb}=10 \%\end{array}$ & $9.7 \pm 0.1$ & $\begin{array}{l}\text { Respiratory response to } \\
\text { prolonged hypoxia, no } \\
\text { differences between groups }\end{array}$ \\
\hline 56 & 2001 & Zevin & 12 healthy smokers & $\begin{array}{l}1200-1500 \text { ppm and } \\
\text { smoking of at least } 20 \\
\text { cigarettes per day } \\
\text { for } 7 \text { days }\end{array}$ & $5 \pm 1 \%$ & $\begin{array}{l}\text { No differences in blood } \\
\text { pressure or respiratory } \\
\text { rate; analysis of platelet } \\
\text { factor } 4 \text { and urine } \\
\text { epinephrine and } \\
\text { norepinephrine }\end{array}$ \\
\hline 58 & 2005 & Mayr & 9 volunteers & $\begin{array}{l}500 \text { ppm for } 1 \mathrm{~h} \text { after } \\
\text { intravenous LPS } \\
\text { injection ( } 2 \mathrm{ng} / \mathrm{kg} \mathrm{BW} \text { ) }\end{array}$ & $6.5-7.7 \%$ & $\begin{array}{l}\text { TNF, IL-1, IL-6, IL-8 } \\
\text { concentrations in } \\
\text { plasma showed } \\
\text { no differences }\end{array}$ \\
\hline 62 & 2005 & Resch & 15 volunteers & 500 ppm for 1 hour & $\begin{array}{l}8.5 \pm \\
0.9 \%\end{array}$ & $\begin{array}{l}\text { Significant increase } \\
\text { in retinal and } \\
\text { choroidal blood flow }\end{array}$ \\
\hline 59 & 2007 & Bathoorn & 20 COPD patients & $\begin{array}{l}100-125 \text { ppm CO for } 2 \\
\text { h on } 4 \text { consecutive days }\end{array}$ & $4.5 \%$ & $\begin{array}{l}\text { Trend in the reduction } \\
\text { of sputum eosinophils, } \\
\text { improvement in response } \\
\text { to metacholine }\end{array}$ \\
\hline 57 & 2009 & Rhodes & 6 subjects & $\begin{array}{l}100 \text { ppm for } 1 \mathrm{~h} \text { for } \\
5 \text { days }\end{array}$ & $\begin{array}{l}3.3 \pm \\
0.6 \%\end{array}$ & $\begin{array}{l}\text { Significant increase in } \\
\text { SOD, HO-1, mitofusin, } \\
\text { ATPase- } 6 \text { and COX-1 } \\
\text { proteins due to CO } \\
\text { inhalation }\end{array}$ \\
\hline 60 & 2015 & Pecorella & 19 subjects & $\begin{array}{l}200 \text { ppm for } 1 \mathrm{~h} \text { for } \\
5 \text { days }\end{array}$ & $\begin{array}{l}5.4 \pm \\
0.8 \%\end{array}$ & $\begin{array}{l}\text { Significant increase in } \\
\text { muscle citrate synthase, } \\
\text { mitochondrial density } \\
\text { and GLUT4 }\end{array}$ \\
\hline \multirow[t]{6}{*}{61} & 2016 & Ryan & 18 volunteers & $\begin{array}{l}1.2 \mathrm{~mL} / \mathrm{kg} \text { BW for } 30 \mathrm{~s} \\
\text { for } 10 \text { days }\end{array}$ & $\begin{array}{l}4.4 \pm \\
0.4 \%\end{array}$ & $\begin{array}{l}\text { No changes in haemoglobin } \\
\text { mass, aerobic performance } \\
\text { or peak power exercise } \\
\text { tolerance }\end{array}$ \\
\hline & & & & Studies withdrawn & & \\
\hline & 2007 & NCT00531856 & $\%$ & $\begin{array}{l}5.97 \mathrm{mg} / \mathrm{L} \text { of carbon } \\
\text { monoxide in } 30 \% \\
\text { oxygen post transplantation } \\
\text { (3 different doses) }\end{array}$ & n.a. & $\begin{array}{l}\text { Primary outcome: Evaluate } \\
\text { the safety and tolerability, } \\
\text { secondary: incidence of } \\
\text { delayed graft dysfunction } \\
\text { (study withdrawn) }\end{array}$ \\
\hline & 2012 & NCT01523548 & $\%$ & $\begin{array}{l}150 \text { ppm for } 3 \mathrm{~h} \text { for } \\
3 \text { weeks }\end{array}$ & n.a. & $\begin{array}{l}\text { Primary outcome: Evidence } \\
\text { of a decrease in pulmonary } \\
\text { vascular resistance } \\
\text { post-therapy } \\
\text { (Study withdrawn) }\end{array}$ \\
\hline & 2010 & NCT01050712 & $\%$ & $\begin{array}{l}\text { Depending on a } \\
\text { healthy control group }\end{array}$ & n.a. & $\begin{array}{l}\text { Primary outcome: incidence } \\
\text { and duration of } \\
\text { postoperative ileus } \\
\text { (Study withdrawn) }\end{array}$ \\
\hline & 2012 & NCT01727167 & $\%$ & $200 \mathrm{ppm}$ for $1 \mathrm{~h}$ & n.a. & $\begin{array}{l}\text { Primary outcome: Biochemica } \\
\text { Markers for Mitochondrial } \\
\text { Biogenesis in aortic valve } \\
\text { surgery (Study withdrawn) }\end{array}$ \\
\hline
\end{tabular}


Experimental data showed promising results regarding the application of low-dose carbon monoxide in preclinical models of ARDS [16, 59, 78-82], including some mechanistic considerations, such as the induction of autophagy, the inhibition of mitochondrial dysfunction, inflammasome activation, and an accelerated resolution of the inflammation via special pro-resolving mediators [80, 83-85].

Recently, Fredenburgh and colleagues extended their previous research in baboons and published the first-in-man study regarding the effects of inhaled $\mathrm{CO}$ in sepsisinduced ARDS patients (NCT 02425579) [86]. In this placebo-controlled clinical trial, 12 patients were enrolled. They received treatment with 100 or $200 \mathrm{ppm}$ inhaled CO respectively, aiming to achieve an algorithm-specified $\mathrm{CO}-\mathrm{Hb}$ of $6-8 \%$. The authors were able to show that $\mathrm{CO}$ inhalation is safe in their setting and the $\mathrm{CO}-\mathrm{Hb}$ may not only be measured but can be predicted accurately using the Coburn-Forster-Kane equation. Furthermore, the author found a significant reduction in mtDNA, while there was no reduction in any other biomarker (IL-18 or RIPK3). Although the cohort was small in this phase- 1 trial, there were no statistical differences in $\mathrm{PaO}_{2} / \mathrm{FiO}_{2}$ ratio, the oxygenation index, lung injury score, lactate, or the SOFA score. These results are most promising and show not only the feasibility and safety of inhaled $\mathrm{CO}$, but the translation of pre-clinical data into a relevant clinical setting. For sure, further studies are needed to confirm these results in a larger population.

\section{Idiopathic pulmonary fibrosis}

Idiopathic pulmonary fibrosis (IPF) is a progressive interstitial lung disease, mainly found in older adults and limited to the lungs. Fibroblast proliferation irreversibly destroys the cellular architecture of the lungs, finally leading to respiratory failure and death [87]. While different treatment options and therapeutic agents are standard treatment on intensive care units [88], there has been only little progress over the last years, with the transplantation of the lungs as the only cure in these patients. Apart from environmental and epigenetic factors, the underlying molecular pathway of the disease is quite well understood, suggesting an imbalance between pro- and anti-fibrotic mediators. Part of this imbalance may be exerted by inflammatory proteins such as TNF or IL-1 [87].

Carbon monoxide was able to suppress bleomycin-induced pulmonary fibrosis in as murine model, modulating the mitogen-activated protein kinases as the commonly known targets [89]. Recently, Rosas and colleagues published their results of a phase-2 clinical trials (NIH U01HL105371) in 58 patients with IPF. The aim was to show that low doses of CO (100 and 200 ppm) inhaled twice a day for 12 weeks would decrease IPF-specific gene expressions (such as MMP7 levels) in the peripheral blood as a sign of decreased disease progression [90]. Unfortunately, there were no differences in the treatment arms regarding the clinical effects of carbon monoxide.

\section{Carbon monoxide in acute kidney injury}

Acute kidney failure (AKI) presents a critical illness with increased morbidity and mortality which is common on every ICU these days, especially in patients presenting with progressive comorbidities and rising age. While a variety of classifications (RIFLE, AKIN, KDIGO) are known, creatinine levels are the most effective contributor to this 
graduation, showing the extent of excretory defects [91]. Renal replacement therapy should be avoided as long as possible and treatment options should include experimental strategies such as carbon monoxide to treat one cause of AKI-e.g., renal ischemia and reperfusion injuries. Data exists that renal IRI may be effectively counteracted by low dose administration of carbon monoxide [92].

The authors were able to show that cytochrome $\mathrm{C}$ was suppressed during ischemia while being at normal levels due to $\mathrm{CO}$ inhalation. This may be of special interest in transplant settings, where ex-vivo cold storage is still common. Hanto and colleagues developed a pig kidney allograft model [93]. They demonstrated that the administration of $\mathrm{CO}$ reduced tubular necrosis and apoptosis. On a molecular basis, they analyzed significant changes in the expression of p-selectin and an increase in repair mechanisms. An additional microarray confirmed data of studies in other species, showing that $\mathrm{CO}$ was able to reduce the expression of MCP-1. While apoptotic markers were decreased in their experiments, the authors conclude that low dose $\mathrm{CO}$ may be an alternative treatment option for delayed graft function after transplantation.

Yoshida supplemented kidney transplantation in a porcine setting with $\mathrm{CO}$, reaching $\mathrm{CO}-\mathrm{Hb}$ levels of $7 \pm 1.5 \%$. Survival rates in the CO-treated group reached $100 \%$, while only $80 \%$ survived in the control group. Analysis of the graft 14 days after transplantation revealed a significantly improved histological score, including less tubular damages, fewer focal fibrotic changes, and lower number of infiltrates in the kidneys. The expression of TGF-beta and p-Smad3 was reduced due to CO application. The authors therefore concluded that the ex-vivo exposure to $\mathrm{CO}$ during cold storage may be an easy alterative and an absolutely safe strategy to reduce IRI in renal transplantation [94].

Neto and coworkers analyzed the classical targets of CO (i.e., mRNA for IL-6, IL1beta, TNF-alpha, ICAM-1, heme oxygenase-1, and inducible nitric oxide synthase) in a model of kidney transplantation in rats. Exposure of $250 \mathrm{ppm} \mathrm{CO}$ for $1 \mathrm{~h}$ before and $24 \mathrm{~h}$ after transplantation revealed lower expression of mRNA in these proteins. Moreover, the survival rate was significantly higher in $\mathrm{CO}$ treated rats than in the control group (60 vs. 25 days). Histopathology revealed the same results as in the other experimental protocols: lower injury scores regarding acute tubular necrosis, interstitial hemorrhage, and edema [95]. These findings are in line with the data of Goebel, who demonstrated reduced renal injury after cardiopulmonary bypass and subsequent IRI of the kidney s[9].

Concerning the clinical application of carbon monoxide in humans, there was a most promising clinical trial, which started in 2007 (NCT00531856; Safety and Tolerability Study of inhaled carbon monoxide in Kidney Transplant Patients). In contrast to the other studies, which aimed to inhale $\mathrm{CO}$ in a fixed dose (e.g., $250 \mathrm{ppm}$ ), the investigators used the COVOX device, a small tool giving a specific dose of CO dependent on the bodyweight and the breathing cycle to the participant. Unfortunately, the study was withdrawn early. The primary outcome was to clear safety issues in terms of the new application method.

\section{Carbon monoxide in sepsis}

Sepsis is among the leading causes of death and in-hospital mortality throughout the world [96]. While the cause of sepsis may be different (e.g., pneumogenic sepsis, 
urogenital sepsis, etc.), the best strategy to treat the individual septic cause (intravenous fluid load versus vasopressor treatment) remains uncertain. As our society turns to older ages, septic conditions are more likely to occur. Lately, artificial intelligence was introduced to help physicians to find the best treatment option [97]. The pathophysiology of sepsis is very complex, including interactions of infecting microorganism and bacteria with the immune system of the patient [98] while the response of the host may vary, ranging from no reaction to excessive reaction, triggering further organ dysfunction.

As explained before, $\mathrm{CO}$ is able to regulate and control inflammation, not only in organ dysfunction but also in sepsis [82, 99-101]. This may be of special interest in septic conditions, since phagocytosis of bacteria may re-establish the balance of the immune response. Carbon monoxide is capable of the induction of macrophages, activating autophagic processes for the uptake of bacteria, such as Escherichia col i[83]. While specific trials regarding the $\mathrm{CO}$ administration in septic humans are still missing, there is a wide amount of data, analyzing the effects of $\mathrm{CO}$ in experimental sepsis. These experiments include almost every organ system and ranges from LPS-induced sepsis to myocardial sepsis and ARDS. The experimental data regarding potential treatment options with $\mathrm{CO}$ or CO-RMs in septic models include the classical targets molecules of CO, such as the NLRP3 inflammasome or the MAPK [100, 102]. Apart from ARDS, no other septic or septic-like condition has been treated in humans using $\mathrm{CO}$. Although, the origin of sepsis is multidimensional and differs considerably between humans, $\mathrm{CO}$ may possess the characteristics to maintain the balance between inflammation and resolution in different organ systems [103].

\section{Extracorporeal circulation units}

Cardiac arrest requiring basic and advanced cardiac life support occurs in approximately 250,000 patients in Europe annually and remains the leading cause of death despite advances in treatment options [104]. Mostly of cardiogenic origin (acute myocardial infarction) [105], survival rates are as low as $~ 10 \%$ [106] and if survived, patients suffer from massive constrains in daily life and activity. These include cerebral damage, cognitive deficits, myocardial injury, and limited hemodynamics which determine the patients' prognosis even if return-of-spontaneous circulation has been achieved. While conventional cardiopulmonary resuscitation strategies did not improve overall survival significantly over the last years, alternative therapies such as extracorporeal CPR (E-CPR) are emerging $[107,108]$ showing first data of improved survival rates and enhanced neurological outcome after in-hospital-cardiac arrest. Beside the opportunity and promising beneficial effects in using any form of extracorporeal circulation unit, one must be aware of the side effects (e.g., renal failure etc.) [109].

Recently, Wollborn and colleagues introduced a new method on administering carbon monoxide via CO-RM (Beck-1) safely to an extracorporeal circulation unit while separating any transition metal component from the bloodstream of the circulation unit [110]. As a consequence, they were able to demonstrated improved hemodynamics and enhanced cardiac function in a porcine model of cardiac arrest and subsequent E-CPR with CO supplementation [111]. Macro- and microcirculation showed CO-dependent constancy against the otherwise harmful ECLS System. Cardiac tissue swelling was reduced as well as the expression of Troponin-T. Furthermore, the authors were able to 
show that the left ventricular ejection fraction and the VTI of the left ventricle was constantly higher in animals with CO administration during and after ECLS using transesophageal echocardiography. These effects were in line with following results, showing improved renal function after ECLS implementation and CO supplementation. Serum parameters of renal function (creatinine and NGAL) as well as a renal injury score resulting from histological analysis revealed a significant decrease due to $\mathrm{CO}$ administration [112]. Although the study was not performed in humans [113], the authors describe a well-established model of a relevant clinical condition. Apart from the usual focus on the molecular mechanism, the authors focused on danger-associated molecular patterns (DAMPS) as the targets for CO. Among these, IL-6, HMGB-1, Cytochrom$\mathrm{C}$, and $\mathrm{HO}-1$ were analyzed and displayed significant changes due to $\mathrm{CO}$ administration. Taken together, a new therapeutic approach of high clinical relevance in treating cardiac arrest and its sequelae has been reported. Regarding the safe and fast onset of $\mathrm{CO}$ delivery during extracorporeal resuscitation, a foundation has been created for a new generation of $\mathrm{CO}$ delivery protocols with high translational significance.

\section{Clinical trials initiated}

Apart from the many studies performed in humans, research is still ingoing. To-date, there are at least two listed trials, aiming to support the data generated so far. The first study, which is already recruiting patients, again aims to treat the acute respiratory distress syndrome. Two different treatment arms have been initiated in this phase-II trial: the administration of carbon monoxide will be $100 \mathrm{ppm}$ and $200 \mathrm{ppm}$ respectively (NCT02425579 [100 ppm] and NCT03799874 [200 ppm]). Moreover, the first-in-man study to evaluate the effects of oral administration of a formulation to induce HO-1 in order to increase endogenous carbon monoxide production (http://www.hillhurstbio. com/hbi-002). This study will be performed in healthy volunteers and is yet to start recruitment (NCT03926819: A study to assess the safety and pharmacokinetics of HBI002, an oral carbon monoxide therapeutic in healthy volunteers). It will be most exciting for both trials to discuss the results, which are expected to be present in the next years.

\section{Summary and conclusions}

Carbon monoxide should no longer be considered as a toxic agent only. While being generated endogenously, its effects and its specific molecular mechanism has been investigated in a broad variety of different models and disease conditions. It has been demonstrated that it may be implicated in a safe yet effective manner. Although clinical studies are rare and patient numbers included in these studies are low, carbon monoxide remains one of the most promising substances with great potential regarding the future development of certain critical illnesses.

The timing of $\mathrm{CO}$ application may be of crucial interest. A prophylactic treatment (e.g., in organ donor settings like living donation) may alter other target molecules than a therapeutic management of sepsis or AKI. In most cases, a prophylactic treatment is not possible-this is one reason why pre-conditioning experiments vanished over the last years. More likely, patients present with a certain degree of organ dysfunction, thus in need of a therapeutic alternative. In contrast to other experimental agents, $\mathrm{CO}$ offers both, the prophylactic conditioning in a known but yet not acute organ dysfunction 
and the therapeutic treatment option in case of severe organ dysfunction. In most cases of human research, $\mathrm{CO}$ has been given as a therapeutic agent, to counteract systemic or organ damage.

Given the large number of published work on CO's potentially beneficial properties in different organ systems, we should not cold-shoulder $\mathrm{CO}$ because of its known toxic effects. Carbon monoxide is an attractive agent while being cheap, simple to administer, and available (in contrast to other gaseous mediators). A wide therapeutic window may open up offering new methods in treating special organ failure either by inhalation or by specific transport of CO-RMs to the tissue of interest.

While carbon monoxide for sure is no magic bullet, it may help to alter especially overwhelming inflammatory conditions in ARDS, AKI, sepsis, transplant settings, or in patient in need of extracorporeal circulation. With the option of different CO-RMs to delivery carbon monoxide tailored to a specific disease to a certain organ or tissue at a particular time, we face the future not only regarding drug development but also in treatment options. While Hooper and colleagues asked "Where is the clinical breakthrough of HO-1 and CO therapeutics?" [114], we should start to give the answers to these and other questions providing larger studies with relevant clinical endpoints.

Acknowledgments

Not applicable.

Authors' contributions

U.G designed the strategy, performed the literature review, and drafted the manuscript. J.W. performed the literature review, revised the manuscript for important intellectual content. Both authors read and approved the final manuscript.

Funding

This work was supported by The German Research Foundation (DFG); Grant numbers: WO 2209/2-1 and GO 2158/6-1.

Availability of data and materials

Not applicable.

Ethics approval and consent to participate

Not applicable.

Consent for publication

All authors consent to publication.

Competing interests

Jakob Wollborn and Ulrich Goebel have a pending patent regarding extracorporeal carbon monoxide application (No.: 18155947.7-1115/3524290)

\section{Author details}

${ }^{1}$ Department of Anaesthesiology and Critical Care, St. Franziskus-Hospital, Hohenzollernring 70, 48145 Münster, Germany. ${ }^{2}$ Department of Anaesthesiology and Critical Care, Medical Centre - University of Freiburg, Faculty of Medicine, Freiburg im Breisgau, Germany.

Received: 8 October 2019 Accepted: 5 January 2020

Published online: 09 January 2020

References

1. Davies IJ (1914) Two cases of erythema due to carbon monoxide poisoning. Proc R Soc Med 7:237-238

2. Haldane J (1927) Carbon monoxide as a tissue poison. Biochem J 21:1068-1075

3. Douglas CG, Haldane JS, Haldane J (1912) The laws of combination of haemoglobin with carbon monoxide and oxygen. J Physiol 44:275-304

4. Coburn RF (1925) Endogenous carbon monoxide production. N Engl J Med 282:207-209

5. Sjöstrand T (1949) Endogenous formation of carbon monoxide in man under normal and pathological conditions. Scand J Clin Lab Investig 1:201-214. https://doi.org/https://doi.org/10.3109/00365514909069943

6. Coburn RF, BLAKEMORE WS, FORSTER RE (1963) Endogenous carbon monoxide production in man. J Clin Invest 42: 1172-1178. https://doi.org/https://doi.org/10.1172/JCl104802

7. Coburn RF, Williams WJ, White P, Kahn SB (1967) The production of carbon monoxide from hemoglobin in vivo. J Clin Invest 46:346-356. https://doi.org/https://doi.org/10.1172/JCl105536 
8. Goebel U, Siepe M, Mecklenburg A, et al (2008) Carbon monoxide inhalation reduces pulmonary inflammatory response during cardiopulmonary bypass in pigs. Anesthesiology 108:1025-1036. https://doi.org/https://doi.org/10.1097/ALN.0b013e3181733115

9. Goebel U, Siepe M, Schwer Cl, et al (2010) Inhaled carbon monoxide prevents acute kidney injury in pigs after cardiopulmonary bypass by inducing a heat shock response. Anesth Analg 111:29-37. https://doi.org/https://doi.org/10.1213/ANE.0b013e3181e0cca4

10. Biermann J, Lagrèze WA, Dimitriu C, et al (2010) Preconditioning with inhalative carbon monoxide protects rat retinal ganglion cells from ischemia/reperfusion injury. Invest Opthalmol Vis Sci 51:3784-3788. https://doi.org/https://doi.org/ 10.1167/iovs.09-4894

11. Schallner N, Fuchs M, Schwer Cl, et al (2012) Postconditioning with inhaled carbon monoxide counteracts apoptosis and neuroinflammation in the ischemic rat retina. PloS one 7:e46479-e46414. https://doi.org/https://doi.org/10.1371/ journal.pone.0046479

12. Schallner N, Schwemmers S, Schwer Cl, et al (2011) p38ß-regulated induction of the heat shock response by carbon monoxide releasing molecule CORM-2 mediates cytoprotection in lung cells in vitro. Eur J Pharmacol 670:58-66. https:// doi.org/https://doi.org/10.1016/j.ejphar.2011.08.028

13. Ulbrich F, Hagmann C, Buerkle H, et al (2017) The Carbon monoxide releasing molecule ALF-186 mediates antiinflammatory and neuroprotective effects via the soluble guanylate cyclase $\backslash s, 1$ in rats' retinal ganglion cells after ischemia and reperfusion injury. 1-14. https://doi.org/https://doi.org/10.1186/s12974-017-0905-7

14. Otterbein LE, Bach FH, Alam J, et al (2000) Carbon monoxide has anti-inflammatory effects involving the mitogenactivated protein kinase pathway. Nat Med 6:422-428. https://doi.org/https://doi.org/10.1038/74680

15. Motterlini R, Foresti R (2017) Biological signaling by carbon monoxide and carbon monoxide-releasing molecules. Am J Physiol Cell Physiol 312:C302-C313. https://doi.org/https://doi.org/10.1152/ajpcell.00360.2016

16. Ryter SW, Ma KC, Choi AMK (2018) Carbon monoxide in lung cell physiology and disease. Am J Physiol Cell Physiol 314 : C211-C227. https://doi.org/https://doi.org/10.1152/ajpcell.00022.2017

17. Tenhunen R, Marver HS, Schmid R (1968) The enzymatic conversion of heme to bilirubin by microsomal heme oxygenase. Proc Natl Acad Sci U S A 61:748-755. https://doi.org/https://doi.org/10.1073/pnas.61.2.748

18. Maines MD, Trakshel GM, Kutty RK (1986) Characterization of two constitutive forms of rat liver microsomal heme oxygenase. Only one molecular species of the enzyme is inducible. J Biol Chem 261:411-419

19. Yachie A, Niida Y, Wada T et al (1999) Oxidative stress causes enhanced endothelial cell injury in human heme oxygenase-1 deficiency. J Clin Invest 103:129-135

20. Hoetzel A, Schmidt R (2010) Regulatory role of anesthetics on heme oxygenase-1. Curr Drug Targets 11:1495-1503. https://doi.org/https://doi.org/10.2174/1389450111009011495

21. Beck-Schimmer B, Breitenstein S, Urech S et al (2008) A randomized controlled trial on pharmacological preconditioning in liver surgery using a volatile anesthetic. Ann Surg 248:909-918

22. Levy RJ (2016) Anesthesia-related carbon monoxide exposure. Anesth Analg 123:670-681. https://doi.org/https://doi.org/ 10.1213/ANE.0000000000001461

23. Goebel U, Siepe M, Mecklenburg A, et al (2008) Reduced pulmonary inflammatory response during cardiopulmonary bypass: effects of combined pulmonary perfusion and carbon monoxide inhalation. Eur J Cardiothorac Surg 34:11651172. https://doi.org/https://doi.org/10.1016/j.ejcts.2008.07.031

24. Loop T, Schlensak C, Goebel U (2011) Cytoprotection by inhaled carbon monoxide before cardiopulmonary bypass in preclinical models. Curr Pharm Biotechnol 13:1-6

25. Otterbein LE, Otterbein SL, Ifedigbo E, et al (2003) MKK3 mitogen-activated protein kinase pathway mediates carbon monoxide-induced protection against oxidant-induced lung injury. Am J Pathol 163:2555-2563. https://doi.org/https:// doi.org/10.1016/S0002-9440(10)63610-3

26. Morse D, Pischke SE, Zhou Z et al (2003) Suppression of inflammatory cytokine production by carbon monoxide involves the JNK pathway and AP-1. J Biol Chem 278:36993-36998

27. Foresti R, Bani-Hani MG, Motterlini R (2008) Use of carbon monoxide as a therapeutic agent: promises and challenges. Intensive Care Med 34:649-658. https://doi.org/https://doi.org/10.1007/s00134-008-1011-1

28. Motterlini R, Clark JE, Foresti R, et al (2002) Carbon monoxide-releasing molecules: characterization of biochemical and vascular activities. Circ Res 90:E17-E24. https://doi.org/https://doi.org/10.1161/hh0202.104530

29. Anna Christin Kautz PCKCJ (2016) CO-releasing molecule (CORM) conjugate systems. Dalton Trans 45:18045-18063. https://doi.org/https://doi.org/10.1039/c6dt03515a

30. Foresti R, Hammad J, Clark JE, et al (2004) Vasoactive properties of CORM-3, a novel water-soluble carbon monoxidereleasing molecule. Br J Pharmacol 142:453-460. https://doi.org/https://doi.org/10.1038/sj.bjp.0705825

31. Motterlini R, Mann BE, Johnson TR, et al (2003) Bioactivity and pharmacological actions of carbon monoxide-releasing molecules. Curr Pharm Des 9:2525-2539. https://doi.org/https://doi.org/10.2174/1381612033453785

32. Chlopicki S, Olszanecki R, Marcinkiewicz E, et al (2006) Carbon monoxide released by CORM-3 inhibits human platelets by a mechanism independent of soluble guanylate cyclase. Cardiovasc Res 71:393-401. https://doi.org/https://doi.org/ 10.1016/j.cardiores.2006.03.011

33. Alberto R, Motterlini R (2007) Chemistry and biological activities of CO-releasing molecules (CORMs) and transition metal complexes. Dalton Trans 1651-1660. https://doi.org/https://doi.org/10.1039/b701992k

34. Motterlini R, Haas B, Foresti R (2012) Emerging concepts on the anti-inflammatory actions of carbon monoxide-releasing molecules (CO-RMs). Med Gas Res 2:28. https://doi.org/https://doi.org/10.1186/2045-9912-2-28

35. Motterlini R, Sawle P, Hammad J, et al (2005) CORM-A1: a new pharmacologically active carbon monoxide-releasing molecule. FASEB J 19:284-286. https://doi.org/https://doi.org/10.1096/fj.04-2169fje

36. Pfeiffer H, Rojas A, Niesel J, Schatzschneider U (2009) Sonogashira and "Click" reactions for the N-terminal and side-chain functionalization of peptides with $[\mathrm{Mn}(\mathrm{CO}) 3(\mathrm{tpm})]+$-based $\mathrm{CO}$ releasing molecules (tpm = tris(pyrazolyl)methane). Dalton transactions (Cambridge, England: 2003) 4292-4298. https://doi.org/https://doi.org/10.1039/b819091g

37. Matson JB, Webber MJ, Tamboli VK, et al (2012) A peptide-based material for therapeutic carbon monoxide delivery. Soft Matter 8:6689-6692. https://doi.org/https://doi.org/10.1039/C2SM25785H

38. Stamellou E, Storz D, Botov S, et al (2014) Different design of enzyme-triggered CO-releasing molecules (ET-CORMs) reveals quantitative differences in biological activities in terms of toxicity and inflammation. Redox Biol 2:739-748. https://doi.org/https://doi.org/10.1016/j.redox.2014.06.002 
39. Romanski S, Stamellou E, Jaraba JT, et al (2013) Enzyme-triggered CO-releasing molecules (ET-CORMs): evaluation of biological activity in relation to their structure. Free Radic Biol Med 65:78-88. https://doi.org/https://doi.org/10.1016/j. freeradbiomed.2013.06.014

40. Motterlini R, Otterbein LE (2010) The therapeutic potential of carbon monoxide. 1-16. https://doi.org/https://doi.org/10. $1038 / \mathrm{nrd} 3228$

41. Mann BE (2012) CO-releasing molecules: a personal view. Organometallics 31:5728-5735. https://doi.org/https://doi.org/ 10.1021/om300364a

42. Ji X, Damera K, Zheng Y, et al (2016) Toward carbon monoxide-based therapeutics: critical drug delivery and developability issues. Journal of pharmaceutical sciences 105:406-416. https://doi.org/https://doi.org/10.1016/j.xphs.2015.10.018

43. Otterbein LE (2009) The evolution of carbon monoxide into medicine. Respir Care 54:925-932

44. Kramkowski K, Leszczynska A, Mogielnicki A, et al (2012) Antithrombotic properties of water-soluble carbon monoxide-releasing molecules. Arterioscler Thromb Vasc Biol 32:2149-2157. https://doi.org/https://doi.org/10.1161/ATVBAHA.112.253989/-/DC1

45. Brugger J, Schick MA, Brock RW, et al (2010) Carbon monoxide has antioxidative properties in the liver involving p38 MAP kinase pathway in a murine model of systemic inflammation. Microcirculation 17:504-513. https://doi.org/https:// doi.org/10.1111/j.1549-8719.2010.00044.x

46. Song R, Mahidhara RS, Zhou Z, et al (2004) Carbon monoxide inhibits T lymphocyte proliferation via caspase-dependent pathway. J Immunol 172:1220-1226. https://doi.org/https://doi.org/10.4049/jimmunol.172.2.1220

47. Ishikawa K (2003) Heme oxygenase-1 against vascular insufficiency: roles of atherosclerotic disorders. Curr Pharm Des 9: 2489-2497. https://doi.org/https://doi.org/10.2174/1381612033453767

48. Julia Stifter, Felix Ulbrich, Ulrich Goebel et al (2017) Neuroprotection and neuroregeneration of retinal ganglion cells after intravitreal carbon monoxide release. 1-24. https://doi.org/https://doi.org/10.1371/journal.pone.0188444

49. McRae KE, Pudwell J, Peterson N, Smith GN (2019) Inhaled carbon monoxide increases vasodilation in the microvascular circulation. Microvasc Res 123:92-98. https://doi.org/https://doi.org/10.1016/j.mvr.2019.01.004

50. Tamion F, Richard V, Lyoumi S, et al (1999) Induction of haem oxygenase contributes to the synthesis of proinflammatory cytokines in re-oxygenated rat macrophages: role of cGMP. Cytokine 11:326-333. https://doi.org/https:// doi.org/10.1006/cyto.1998.0441

51. Wu M-S, Chien C-C, Chang J, Chen Y-C (2019) Pro-apoptotic effect of haem oxygenase-1 in human colorectal carcinoma cells via endoplasmic reticular stress. J Cell Mol Med 23:5692-5704. https://doi.org/https://doi.org/10.1111/jcmm.14482

52. Almeida AS, Soares NL, Vieira M, et al (2016) Carbon monoxide releasing molecule-A1 (CORM-A1) improves neurogenesis: increase of neuronal differentiation yield by preventing cell death. PLoS One 11:e0154781. https://doi.org/ https://doi.org/10.1371/journal.pone.0154781

53. Schallner N, Otterbein LE (2015) Friend or foe? Carbon monoxide and the mitochondria. Front Physiol 6:17. https://doi. org/https://doi.org/10.3389/fphys.2015.00017

54. Sawle P, Foresti R, Mann BE, et al (2005) Carbon monoxide-releasing molecules (CO-RMs) attenuate the inflammatory response elicited by lipopolysaccharide in RAW264.7 murine macrophages. Br J Pharmacol 145:800-810. https://doi.org/ https://doi.org/10.1038/sj.bjp.0706241

55. Bani-Hani MG, Greenstein D, Mann BE, et al (2006) Modulation of thrombin-induced neuroinflammation in BV-2 microglia by carbon monoxide-releasing molecule 3. J Pharmacol Exp Ther 318:1315-1322. https://doi.org/https://doi. org/10.1124/jpet.106.104729

56. Maines MD, Mark JA, Ewing JF (1993) Heme oxygenase, a likely regulator of cGMP production in the brain: induction in vivo of HO-1 compensates for depression in NO synthase activity. Mol Cell Neurosci 4:396-405. https://doi.org/ https://doi.org/10.1006/mcne.1993.1050

57. Wu CC, Szabo C, Chen SJ, et al (1994) Activation of soluble guanylyl cyclase by a factor other than nitric oxide or carbon monoxide contributes to the vascular hyporeactivity to vasoconstrictor agents in the aorta of rats treated with endotoxin. Biochem Biophys Res Commun 201:436-442. https://doi.org/https://doi.org/10.1006/bbrc.1994.1720

58. Wang XM, Kim HP, Nakahira K, et al (2009) The heme oxygenase-1/carbon monoxide pathway suppresses TLR4 signaling by regulating the interaction of TLR4 with caveolin-1. J Immunol 182:3809-3818. https://doi.org/https://doi. org/10.4049/jimmunol.0712437

59. Hoetzel A, Schmidt R, Vallbracht S, et al (2009) Carbon monoxide prevents ventilator-induced lung injury via caveolin-1* Critical Care Med 37:1708-1715. https://doi.org/https://doi.org/10.1097/CCM.0b013e31819efa31

60. Bihari A, Chung KA, Cepinskas G, et al (2019) Carbon monoxide-releasing molecule-3 (CORM-3) offers protection in an in vitro model of compartment syndrome. Microcirculation e12577. https://doi.org/https://doi.org/10.1111/micc.12577

61. Pena AC, Penacho N, Mancio-Silva L, et al (2012) A novel carbon monoxide-releasing molecule fully protects mice from severe malaria. Antimicrob Agents Chemother 56:1281-1290. https://doi.org/https://doi.org/10.1128/AAC.05571-11

62. Kamat PK, Ahmad AS, Dore S (2019) Carbon monoxide attenuates vasospasm and improves neurobehavioral function after subarachnoid hemorrhage. Arch Biochem Biophys 108117. https://doi.org/https://doi.org/10.1016/j.abb.2019.108117

63. Drummond HA, Mitchell ZL, Abraham NG, Stec DE (2019) Targeting heme oxygenase-1 in cardiovascular and kidney disease. Antioxidants 8:181-113. https://doi.org/https://doi.org/10.3390/antiox8060181

64. Stewart RD, Peterson JE, Fisher TN, et al (1973) Experimental human exposure to high concentrations of carbon monoxide. Arch Environ Health 26:1-7. https://doi.org/https://doi.org/10.1080/00039896.1973.10666210

65. Peterson JE, Stewart RD (1975) Predicting the carboxyhemoglobin levels resulting from carbon monoxide exposures. J Appl Physiol 39:633-638. https://doi.org/https://doi.org/10.1152/jappl.1975.39.4.633

66. Ren X, Dorrington KL, Robbins PA (2001) Respiratory control in humans after $8 \mathrm{~h}$ of lowered arterial PO2, hemodilution, or carboxyhemoglobinemia. J Appl Physiol (1985) 90:1189-1195. https://doi.org/https://doi.org/10.1152/jappl.2001.90.4.1189

67. Hausberg M, Somers VK (1997) Neural circulatory responses to carbon monoxide in healthy humans. Hypertension 29: 1114-1118. https://doi.org/https://doi.org/10.1161/01.hyp.29.5.1114

68. Zevin S, Saunders S, Gourlay SG, et al (2001) Cardiovascular effects of carbon monoxide and cigarette smoking. J Am Coll Cardiol 38:1633-1638. https://doi.org/https://doi.org/10.1016/s0735-1097(01)01616-3

69. Rhodes MA, Carraway MS, Piantadosi CA, et al (2009) Carbon monoxide, skeletal muscle oxidative stress, and mitochondrial biogenesis in humans. Am J Physiol Heart Circ Physiol 297:H392-H399. https://doi.org/https://doi.org/10. 1152/ajpheart.00164.2009 
70. Mayr FB, Spiel A, Leitner J, et al (2005) Effects of carbon monoxide inhalation during experimental endotoxemia in humans. Am J Respir Crit Care Med 171:354-360. https://doi.org/https://doi.org/10.1164/rccm.200404-4460C

71. Bathoorn E, Slebos D-J, Postma DS, et al (2007) Anti-inflammatory effects of inhaled carbon monoxide in patients with COPD: a pilot study. Eur Respir J 30:1131-1137. https://doi.org/https://doi.org/10.1183/09031936.00163206

72. Pecorella SRH, Potter JVF, Cherry AD, et al (2015) The HO-1/CO system regulates mitochondrial-capillary density relationships in human skeletal muscle. Am J Physiol Lung Cell Mol Physiol 309:L857-L871. https://doi.org/https://doi. org/10.1152/ajplung.00104.2015

73. Ryan BJ, Goodrich JA, Schmidt W, et al (2016) Ten days of intermittent, low-dose carbon monoxide inhalation does not significantly alter hemoglobin mass, aerobic performance predictors, or peak-power exercise tolerance. Int J Sports Med 37:884-889. https://doi.org/https://doi.org/10.1055/s-0042-108197

74. Resch H, Zawinka C, Weigert, G., Schmetterer, L et al (2005) Inhaled carbon monoxide increases retinal and choroidal blood flow in healthy humans. Invest Opthalmol Vis Sci 46:4275-4276. https://doi.org/https://doi.org/10.1167/iovs.05-0417

75. Montani D, Chaumais M-C, Guignabert C, et al (2014) Targeted therapies in pulmonary arterial hypertension. Pharmacol Ther 141:172-191. https://doi.org/https://doi.org/10.1016/j.pharmthera.2013.10.002

76. Bellani G, Laffey JG, Pham T, et al (2016) Epidemiology, patterns of care, and mortality for patients with acute respiratory distress syndrome in intensive care units in 50 countries. JAMA 315:788-800. https://doi.org/https://doi.org/10.1001/ jama.2016.0291

77. Angus DC, Linde-Zwirble WT, Lidicker J, et al (2001) Epidemiology of severe sepsis in the United States: analysis of incidence, outcome, and associated costs of care. Crit Care Med 29:1303-1310. https://doi.org/https://doi.org/10.1097/ 00003246-200107000-00002

78. Dolinay T, Szilasi M, Liu M, Choi AMK (2004) Inhaled carbon monoxide confers antiinflammatory effects against ventilator-induced lung injury. Am J Respir Crit Care Med 170:613-620. https://doi.org/https://doi.org/10.1164/rccm. 200401-0230C

79. Otterbein LE, Mantell LL, Choi AM (1999) Carbon monoxide provides protection against hyperoxic lung injury. Am J Physiol 276:L688-L694. https://doi.org/https://doi.org/10.1152/ajplung.1999.276.4.L688

80. Fredenburgh LE, Kraft BD, Hess DR, et al (2015) Effects of inhaled CO administration on acute lung injury in baboons with pneumococcal pneumonia. Am J Physiol Lung Cell Mol Physiol 309:L834-L846. https://doi.org/https://doi.org/10. 1152/ajplung.00240.2015

81. Mitchell LA, Channell MM, Royer CM, et al (2010) Evaluation of inhaled carbon monoxide as an anti-inflammatory therapy in a nonhuman primate model of lung inflammation. Am J Physiol Lung Cell Mol Physiol 299:L891-L897. https://doi.org/https://doi.org/10.1152/ajplung.00366.2009

82. Nakahira K, Choi AMK (2015) Carbon monoxide in the treatment of sepsis. Am J Physiol Lung Cell Mol Physiol 309 L1387-L1393. https://doi.org/https://doi.org/10.1152/ajplung.00311.2015

83. Lee S, Lee S-J, Coronata AA, et al (2014) Carbon monoxide confers protection in sepsis by enhancing beclin 1-dependent autophagy and phagocytosis. Antioxid Redox Signal 20:432-442. https://doi.org/https://doi.org/10.1089/ars.2013.5368

84. Jung S-S, Moon J-S, XU J-F, et al (2015) Carbon monoxide negatively regulates NLRP3 inflammasome activation in macrophages. Am J Physiol Lung Cell Mol Physiol 308:L1058-L1067. https://doi.org/https://doi.org/10.1152/ajplung.00400.2014

85. Chiang N, Shinohara M, Dalli J, et al (2013) Inhaled carbon monoxide accelerates resolution of inflammation via unique proresolving mediator-heme oxygenase-1 circuits. J Immunol 190:6378-6388. https://doi.org/https://doi.org/10.4049/ jimmunol.1202969

86. Fredenburgh LE, Perrella MA, Barragan-Bradford D, et al (2018) A phase I trial of low-dose inhaled carbon monoxide in sepsis-induced ARDS. JCI Insight 3:L688-L618. https://doi.org/https://doi.org/10.1172/jci.insight.124039

87. Kinoshita T, Goto T (2019) Molecular mechanisms of pulmonary fibrogenesis and its progression to lung cancer: a review. Int J Mol Sci 20:1461-1416. https://doi.org/https://doi.org/10.3390/ijms20061461

88. Kolb M, Raghu G, Wells AU, et al (2018) Nintedanib plus Sildenafil in patients with idiopathic pulmonary fibrosis. N Engl J Med 379:1722-1731. https://doi.org/https://doi.org/10.1056/NEJMoa1811737

89. Zhou Z, Song R, Fattman CL, et al (2005) Carbon monoxide suppresses bleomycin-induced lung fibrosis. Am J Pathol 166:27-37. https://doi.org/https://doi.org/10.1016/S0002-9440(10)62229-8

90. Rosas IO, Goldberg HJ, Collard HR, et al (2018) A phase II clinical trial of low-dose inhaled carbon monoxide in idiopathic pulmonary fibrosis. Chest 153:94-104. https://doi.org/https://doi.org/10.1016/j.chest.2017.09.052

91. Barasch J, Zager R, Bonventre JV (2017) Acute kidney injury: a problem of definition. Lancet 389:779-781. https://doi.org/ https://doi.org/10.1016/S0140-6736(17)30543-3

92. Nakao A, Yamada T, Kohama K, et al (2014) Application of carbon monoxide for treatment of acute kidney injury. Acute Medicine \& Surgery 1:127-134. https://doi.org/https://doi.org/10.1002/ams2.38

93. Hanto DW, Maki T, Yoon MH, et al (2010) Intraoperative administration of inhaled carbon monoxide reduces delayed graft function in kidney allografts in Swine. Am J Transplant 10:2421-2430. https://doi.org/https://doi.org/10.1111/j.16006143.2010.03289.x

94. Yoshida J, Ozaki KS, Nalesnik MA, et al (2010) Ex vivo application of carbon monoxide in UW solution prevents transplant-induced renal ischemia/reperfusion injury in pigs. Am J Transplant 10:763-772. https://doi.org/https://doi.org/ 10.1111/j.1600-6143.2010.03040.x

95. Neto JS, Nakao A, Kimizuka K et al (2004) Protection of transplant-induced renal ischemia-reperfusion injury with carbon monoxide. Am J Physiol Renal Physiol 287:F979-F989

96. Chen AX, Simpson SQ, Pallin DJ (2019) Sepsis Guidelines. N Engl J Med 380:1369-1371. https://doi.org/https://doi.org/ 10.1056/NEJMclde1815472

97. Komorowski M, Celi LA, Badawi O, et al (2018) The artificial intelligence clinician learns optimal treatment strategies for sepsis in intensive care. Nat Med 24:1716-1720. https://doi.org/https://doi.org/10.1038/s41591-018-0213-5

98. Angus DC, van der Poll T (2013) Severe sepsis and septic shock. N Engl J Med 369:2063. https://doi.org/https://doi.org/ 10.1056/NEJMc1312359

99. Jamal Uddin M, Joe Y, Kim S-K, et al (2016) IRG1 induced by heme oxygenase-1/carbon monoxide inhibits LPSmediated sepsis and pro-inflammatory cytokine production. Cell Mol Immunol 13:170-179. https://doi.org/https://doi. org/10.1038/cmi.2015.02 
100. Zhang W, Tao A, Lan T, et al (2017) Carbon monoxide releasing molecule-3 improves myocardial function in mice with sepsis by inhibiting NLRP3 inflammasome activation in cardiac fibroblasts. Basic Res Cardiol 112:16. https://doi.org/ https://doi.org/10.1007/s00395-017-0603-8

101. Unuma K, Aki T, Nagano S, et al (2018) The down-regulation of cardiac contractile proteins underlies myocardial depression during sepsis and is mitigated by carbon monoxide. Biochem Biophys Res Commun 495:1668-1674. https:// doi.org/https://doi.org/10.1016/j.bbrc.2017.12.020

102. Wang X, Qin W, Song M, et al (2016) Exogenous carbon monoxide inhibits neutrophil infiltration in LPS-induced sepsis by interfering with FPR1 via p38 MAPK but not GRK2. Oncotarget 7:34250-34265. https://doi.org/https://doi.org/10. 18632/oncotarget.9084

103. Tsoyi K, Hall SRR, Dalli J, et al (2016) Carbon monoxide improves efficacy of mesenchymal stromal cells during sepsis by production of specialized proresolving lipid mediators. Crit Care Med 44:e1236-e1245. https://doi.org/https://doi.org/10. 1097/CCM.0000000000001999

104. Atwood C, Eisenberg MS, Herlitz J, Rea TD (2005) Incidence of EMS-treated out-of-hospital cardiac arrest in Europe. Resuscitation 67:75-80. https://doi.org/https://doi.org/10.1016/j.resuscitation.2005.03.021

105. Perkins GD, Handley AJ, Koster RW, et al (2015) European Resuscitation Council Guidelines for Resuscitation 2015: Section 2. Adult basic life support and automated external defibrillation. Resuscitation 95:81-99. https://doi.org/https:// doi.org/10.1016/j.resuscitation.2015.07.015

106. Mozaffarian D, Benjamin EJ, Go AS, et al (2016) Heart disease and stroke statistics-2016 update: a report from the American Heart Association. Circulation 133:e38-360. https://doi.org/https://doi.org/10.1161/CIR.0000000000000350

107. Ouweneel DM, Schotborgh JV, Limpens J, et al (2016) Extracorporeal life support during cardiac arrest and cardiogenic shock: a systematic review and meta-analysis. Intensive Care Med 42:1922-1934. https://doi.org/https://doi.org/10.1007/ s00134-016-4536-8

108. Ahn C, Kim W, Cho Y, et al (2016) Efficacy of extracorporeal cardiopulmonary resuscitation compared to conventional cardiopulmonary resuscitation for adult cardiac arrest patients: a systematic review and meta-analysis. Sci Rep 6:34208. https://doi.org/https://doi.org/10.1038/srep34208

109. Husain-Syed F, Ricci Z, Brodie D, et al (2018) Extracorporeal organ support (ECOS) in critical illness and acute kidney injury: from native to artificial organ crosstalk. Intensive Care Med 44:1447-1459. https://doi.org/https://doi.org/10.1007/ s00134-018-5329-z

110. Wollborn J, Hermann C, Goebel U, et al (2018) Overcoming safety challenges in CO therapy - Extracorporeal CO delivery under precise feedback control of systemic carboxyhemoglobin levels. Journal of Controlled Release 279:336344. https://doi.org/https://doi.org/10.1016/j.jconrel.2018.04.017

111. Wollborn J, Steiger C, Ruetten E, et al (2019) Carbon monoxide improves haemodynamics during extracorporeal resuscitation in pigs. Cardiovasc Res 67:75-13. https://doi.org/https://doi.org/10.1093/cvr/cvz075

112. Wollborn J, Schlueter B, Steiger C et al (2019) Extracorporeal resuscitation with carbon monoxide improves renal function by targeting inflammatory pathways in cardiac arrest in pigs. Am J Physiol Renal Physiol. https://doi.org/10. 1152/ajprenal.00241.2019

113. Wollborn J, Ruetten E, Schlueter B, et al (2018) Standardized model of porcine resuscitation using a custom-made resuscitation board results in optimal hemodynamic management. Am J Emerg Med 1-7. https://doi.org/https://doi.org/ 10.1016/j.ajem.2018.01.059

114. Hopper CP, Meinel L, Steiger C, Otterbein LE (2018) Where is the clinical breakthrough of heme oxygenase-1 / carbon monoxide therapeutics? Curr Pharm Des 24:2264-2282. https://doi.org/https://doi.org/10.2174/ 1381612824666180723161811

\section{Publisher's Note}

Springer Nature remains neutral with regard to jurisdictional claims in published maps and institutional affiliations.

\section{Submit your manuscript to a SpringerOpen ${ }^{\circ}$ journal and benefit from:}

- Convenient online submission

- Rigorous peer review

- Open access: articles freely available online

- High visibility within the field

- Retaining the copyright to your article

Submit your next manuscript at $\boldsymbol{\nabla}$ springeropen.com 